\title{
Distribution of Selected Elements in Surficial Marine Sediments of the Northern Gulf of Mexico Continental Shelf and Slope
}

GEOLOGICAL SURVEY PROFESSIONAL PAPER 814

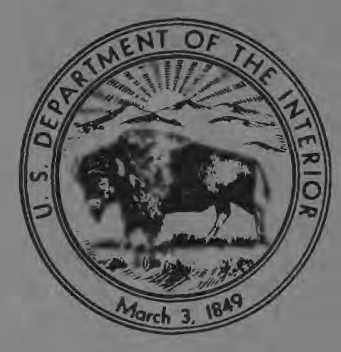




\section{Distribution of Selected Elements in Surficial Marine Sediments of the Northern Gulf of Mexico Continental Shelf and Slope}

By CHARLES W. HOLMES

GEOLOGICAL SURVEY PROFESSIONAL PAPER 814

A study of the distribution of elements

in two continental shelf environments

of different depositional character

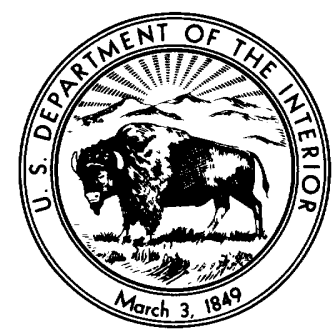

\begin{tabular}{llllll}
\hline UNITED & STATES & GOVERNMENT & PRINTING & OFFICE, WASHINGTON : 1973
\end{tabular} 


\section{UNITED STATES DEPARTMENT OF THE INTERIOR}

ROGERS C. B. MORTON, Secretary

GEOLOGICAL SURVEY

V. E. McKelvey, Director

Library of Congress catalog-card No. 73-600188 


\section{CONTENTS}



\section{ILLUSTRATIONS}

[Plates are in pocket]

Plate 1. Map showing the generalized distribution of surficial marine sediments on the continental shelf and slope of the northern Gulf of Mexico.

2-4. Maps showing the distribution in surficial marine sediments on the continental shelf and slope of the northern Gulf of Mexico of:

2. Barium, boron, calcium, chromium, cobalt, and copper.

3. Iron, lanthanum, lead, magnesium, mang anese, and nickel.

4. Scandium, strontium, titanium, vanadium, yttrium, and zirconium.

\section{TABLES}

TABLE 1. Analytical ranges of detection of elements determined by semiquantitative spectrographic method -..--

2. Geometric means and geometric deviations of elements in the surficial marine sediments on the continental shelf and slope in the northern Gulf of Mexico

3. Average element content in surficial marine sediments of the Gulf shelf and average element content reported for major sedimentary units

4. Bielement correlation coefficient based on analysis of surficial marine sediments on the northern continental shelf and slope of the Gulf of Mexico 

upper limit value is prefaced by "G" signifying "greater than"; concentrations below the limit of determination are noted by " $\mathrm{N}$ " (not detected). If the spectographer detects the presence of an element, but the analytical line is too faint for an accurate estimate of elemental concentration, the elemental values are reported as "L", which denotes that the element is present but in concentrations less than the lower limit of determination.

\section{METHODS OF DATA ANALYSIS}

The values obtained from the analyses for each element were plotted on charts and contoured. From these charts, maps were constructed with patterns representing the field between contour intervals. The contour interval for each map was chosen subjectively to show the regional variations. The patterns represent a subjective smoothing to avoid clutter in the areas of high sample density. Only those elements which were detected in more than 50 percent of the samples have been mapped.

For comparative purposes, the shelf was divided into three segments: (1) the northwestern shelf and upper slope west of the Mississippi River Delta and north of lat $28^{\circ} \mathrm{N}$., (2) the northeastern shelf and slope east of the Mississippi River Delta and north of lat $28^{\circ} \mathrm{N}$., and (3) the south Florida shelf and slope from lat $28^{\circ} \mathrm{N}$. to the Florida Keys. Latitude $28^{\circ}$ was chosen as the southern limit of the northwestern region to exclude Rio Grande sediments. The sediments in the northwestern shelf are primarily noncarbonate clastics, whereas the sediments in the south Florida area are wholly in a carbonate environment. The northeastern area represents the transition zone between the noncarbonate and carbonate areas. Statistical summarization of the elemental composition of each of the three areas allows chemical comparison and differentiation based on sediment type to be made.

The data were computer summarized by a program which yielded a listing of the data, the maximum and minimum values, a histogram plot, the frequency distribution, and a statistical summary which included the geometric mean and geometric deviation. Before these computations were performed, all G (greater than) values were removed from the data by assigning these values to the next higher geometric class midpoints. This type of manipulation was necessary for calcium, manganese, strontium, and zirconium. Justification for this procedure comes from the analysis of the data and known chemical distributions.
The geometric mean and geometric deviation are antilogs of the arithmetic mean and standard deviation of the logarithms of the analytical values. If samples had elemental concentrations less than the lower limit of detection, the geometric mean and deviations were estimated by a censored-distribution method (Cohen, 1959). The geometric mean is a more consistent measure of the central tendency of a frequency distribution than the arithmetic mean and thus is an estimate of the typical or most common concentration of an element. The geometric means and deviations are given in table 2.

The arithmetic means of the analytical data were computed from the estimated geometric means and deviations by using the method described by Miesch (1967), which is based on the techniques presented by Cohen (1959) and Sichel (1952). The arithmetic means listed in table 3 are estimates of geochemical abundance (Miesch, 1967) and are directly comparable to the arithmetic means (geochemical averages) reported in the literature (Shacklette and others, 1971).

Correlation coefficients-those statistical parameters which "measure" the reliability of one variable in predicting another-were calculated on the logs of the analytical values. The computer program ${ }^{1}$ used for these calculations ignores data in which one or more values are qualified. Therefore, the correlation coefficient for some element pairs is based on less than the total number of samples. For these pairs, the data are derived from censored distributions and should be considered as an index of association (A. T. Miesch, written commun., 1971). However, if only a few values are qualified in a large data set, the calculated correlation coefficient may be used for statistical evaluation. The correlation coefficients for the elements in each area are given in table 4.

\section{RESULTS}

The results of this investigation are presented in a series of maps depicting regional elemental patterns (pls. 2-4). The data are also summarized in tables 2-4, which list the geometric means and geometric deviations, the arithmetic means, and correlation coefficients.

Of the 30 elements for which analyses were performed, 18 had sufficient concentrations to be detected in more than 50 percent of the samples; these data are shown on plates $2-4$. Five of the remaining

${ }^{1}$ Selner, G. I., 1968, Correlation analysis. Program No. D0101: U.S. Geol. Survey, Computer Center Division, Denver, Colo. 
TABLE 2.-Geometric means and geometric deviations of elements in the surficial marine sediments on the continental shelf and slope in the northern Gulf of Mexico

[Geometric means reported in parts per million; $N$, number of samples analyzed; N.E., not enough samples had detectable amounts of the element to allow for calculation of measure and deviation]

\begin{tabular}{|c|c|c|c|c|c|c|c|c|}
\hline \multirow[b]{2}{*}{ Element } & \multicolumn{2}{|c|}{$\begin{array}{l}\text { Northwestern shelf } \\
\text { and slope } \\
(N=795)\end{array}$} & \multicolumn{2}{|c|}{$\begin{array}{l}\text { Northeastern shelf } \\
\text { and slope } \\
(N=206)\end{array}$} & \multicolumn{2}{|c|}{$\begin{array}{c}\text { South Florida shelf } \\
\text { and slope } \\
(N=148)\end{array}$} & \multicolumn{2}{|c|}{$\begin{array}{c}\text { Total number } \\
\text { of samples } \\
\text { analyzed } \\
(N=1,304) \\
\end{array}$} \\
\hline & $\begin{array}{c}\text { Geometric } \\
\text { mean }\end{array}$ & $\begin{array}{c}\text { Geometric } \\
\text { deviation }\end{array}$ & $\begin{array}{c}\text { Geometric } \\
\text { mean }\end{array}$ & $\begin{array}{l}\text { Geometric } \\
\text { deviation }\end{array}$ & $\begin{array}{c}\text { Geometric } \\
\text { mean }\end{array}$ & $\begin{array}{l}\text { Geometric } \\
\text { deviation }\end{array}$ & $\begin{array}{l}\text { Geometric } \\
\text { mean }\end{array}$ & $\begin{array}{l}\text { Geometric } \\
\text { deviation }\end{array}$ \\
\hline 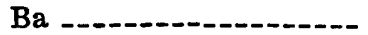 & 480 & 1.56 & 84 & 3.56 & 69 & 2.84 & 295 & 2.96 \\
\hline 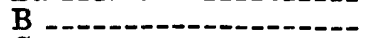 & 55 & 1.86 & 47 & 1.77 & 26 & 1.89 & 48 & 1.91 \\
\hline $\mathrm{Ca}$ & 15,800 & 3.33 & 125,600 & 2.47 & 286,000 . & 1.21 & 40,700 & 5.03 \\
\hline Co & 8 & 1.41 & 7 & 1.44 & 2 & 3.27 & 8 & 1.43 \\
\hline $\mathrm{Cr}$ & 47 & 2.05 & 31 & 2.89 & 26 & 1.88 & 40 & 2.18 \\
\hline $\mathrm{Cu}$ & 10 & 1.70 & 9 & 1.85 & N.E. & N.E. & 10 & 1.81 \\
\hline $\mathrm{Fe}$ & 15,100 & 2.09 & 12,100 & 3.33 & 3,710 & 3.74 & 10,300 & 2.99 \\
\hline - & 32 & 1.79 & 18 & 2.63 & 6 & 2.65 & 25 & 2.04 \\
\hline 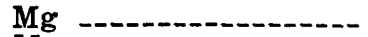 & 7,400 & 1.98 & 12,500 & 2.62 & 24,100 & 1.37 & 10,200 & 2.39 \\
\hline $\mathrm{Mn}$ & 401 & 1.75 & 217 & 4.96 & 95 & 4.34 & 230 & 3.36 \\
\hline $\mathrm{Ni}$ & 19 & 2.07 & 16 & 2.48 & 5 & 3.52 & 17 & 2.21 \\
\hline $\mathrm{Pb}$ & 24 & 1.77 & 23 & 1.99 & N.E. & N.E. & 24 & 1.87 \\
\hline 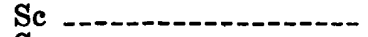 & 9 & 1.54 & 8 & 1.51 & 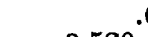 & 4.56 & 9 & 1.55 \\
\hline Sr & 198 & 1.98 & 1,060 & 2.17 & 3,580 & 1.85 & 500 & 4.21 \\
\hline Ti & 2,800 & 1.81 & 820 & 2.97 & 296 & 2.68 & 1,200 & 3.16 \\
\hline $\mathrm{V}$ & 73 & 2.01 & 36 & 2.47 & 19 & 2.29 & 48 & 2.52 \\
\hline $\mathbf{Y}$ & 21 & 1.51 & 18 & 1.53 & 9 & 2.19 & 20 & 1.54 \\
\hline$\overline{\mathbf{Z}} \mathbf{r}$ & 309 & 2.36 & 55 & 2.63 & 11 & 2.26 & 121 & 4.72 \\
\hline
\end{tabular}

${ }^{1}$ Includes 155 samples from west of De Soto Canyon and north of lat $28^{\circ} \mathrm{N}$.

12 elements were found in some samples as follows: Beryllium, in 44.5 percent of the samples, ranging from 1 to $10 \mathrm{ppm}$; molybdenum, in 7.6 percent of the samples, ranging from 5 to $15 \mathrm{ppm}$; niobium, in 34.7 percent of the samples, ranging from 10 to 30 $\mathrm{ppm}$; tin, in 4.3 percent of the samples, ranging from 10 to $500 \mathrm{ppm}$; and zinc, in 0.2 percent of the samples, ranging from 300 to $1,500 \mathrm{ppm}$. The remaining seven elements were looked for in all samples but were not detected. These elements and their lower limit of detection (in parts per million) are as follows: Antimony, 100 ; arsenic, 200; bismuth, 10 ; cadmium, 20 ; gold, 10 ; silver, 0.5 and tungsten, 50.

\section{DISCUSSION AND CONCLUSIONS}

Examination of the maps accompanying this report (pls. 2-4) reveals certain regional variations in the concentrations of the elements. Because of operative bias in the analytical method, mapped patterns

TABLE 3.-Average element content in surficial marine sediments of the Gulf shelf and average element content reported for major sedimentary units

[Data in parts per million; each average represents arithmetic mean; $X$ indicates that only order of magnitude estimate could be made]

\begin{tabular}{|c|c|c|c|c|c|c|c|c|c|c|c|c|c|}
\hline \multirow[b]{3}{*}{ Element } & \multirow{2}{*}{\multicolumn{4}{|c|}{$\begin{array}{l}\text { Gulf shelf marine sediment, } \\
\text { this report }\end{array}$}} & \multicolumn{9}{|c|}{ Worldwide elemental averages of major sedimentary units } \\
\hline & & & & & \multicolumn{4}{|c|}{ Horn and Adams (1966) } & \multicolumn{5}{|c|}{ Turekian and Wedepohl (1961) } \\
\hline & $\begin{array}{l}\text { North- } \\
\text { western } \\
\text { shelf }\end{array}$ & $\begin{array}{l}\text { North- } \\
\text { eastern } \\
\text { shelf }\end{array}$ & $\begin{array}{c}\text { South } \\
\text { Florida } \\
\text { shelf }\end{array}$ & $\begin{array}{l}\text { Total } \\
\text { sam- } \\
\text { ples } 1\end{array}$ & $\begin{array}{l}\text { Car- } \\
\text { bon- } \\
\text { ate }\end{array}$ & Shale & $\begin{array}{l}\text { Sand } \\
\text { stone }\end{array}$ & $\begin{array}{c}\text { Mobile } \\
\text { belt } \\
\text { sedi- } \\
\text { ments } 2\end{array}$ & $\begin{array}{l}\text { Car- } \\
\text { bon- } \\
\text { ate }\end{array}$ & Shale & $\begin{array}{l}\text { Sand- } \\
\text { stone }\end{array}$ & $\begin{array}{l}\text { Deep- } \\
\text { sea } \\
\text { car- } \\
\text { bon- } \\
\text { ate }\end{array}$ & $\begin{array}{c}\text { Deep- } \\
\text { sea } \\
\text { clay }\end{array}$ \\
\hline 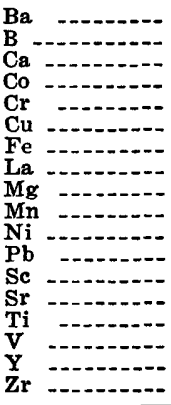 & $\begin{array}{r}509 \\
64 \\
31,760 \\
8 \\
64 \\
11 \\
18,910 \\
37 \\
8,920 \\
442 \\
23 \\
25 \\
9 \\
273 \\
2730 \\
2,730 \\
91 \\
22 \\
431\end{array}$ & $\begin{array}{r}140 \\
56 \\
182,140 \\
5 \\
48 \\
7 \\
75,290 \\
30 \\
19,420 \\
740 \\
21 \\
21 \\
6 \\
1,436 \\
1,400 \\
54 \\
17 \\
89\end{array}$ & $\begin{array}{r}66 \\
31 \\
286,000 \\
3 \\
32 \\
\times \\
8,920 \\
9 \\
24,680 \\
257 \\
10 \\
\times \\
2 \\
4,264 \\
470 \\
25 \\
12 \\
15\end{array}$ & $\begin{array}{r}341 \\
57 \\
151,320 \\
6 \\
52 \\
9 \\
18,450 \\
32 \\
14,920 \\
519 \\
21 \\
21 \\
7 \\
1,300 \\
2,410 \\
77 \\
18 \\
375\end{array}$ & $\begin{array}{r}35 \\
12 \\
272,000 \\
.2 \\
7 \\
4 \\
8,660 \\
6 \\
45,500 \\
385 \\
13 \\
6 \\
1 \\
544 \\
389 \\
13 \\
6 \\
18\end{array}$ & $\begin{array}{r}263 \\
79 \\
22,200 \\
8 \\
427 \\
47 \\
39,600 \\
25 \\
16,600 \\
300 \\
33 \\
20 \\
11 \\
242 \\
4,520 \\
102 \\
12 \\
144\end{array}$ & $\begin{array}{r}199 \\
25 \\
22,200 \\
.5 \\
121 \\
15 \\
21,000 \\
11 \\
8,760 \\
10 \\
3 \\
7 \\
1 \\
24 \\
2,100 \\
21 \\
2 \\
206\end{array}$ & $\begin{array}{r}233 \\
56 \\
26,900 \\
5 \\
295 \\
34 \\
31,100 \\
18 \\
13,900 \\
188 \\
21 \\
15 \\
7 \\
168 \\
3,430 \\
68 \\
8 \\
160 \\
\end{array}$ & $\begin{array}{r}10 \\
20 \\
302,300 \\
.1 \\
11 \\
4 \\
3,800 \\
\times \\
47,000 \\
1,100 \\
20 \\
9 \\
1 \\
610 \\
400 \\
20 \\
30 \\
19\end{array}$ & $\begin{array}{r}580 \\
100 \\
22,100 \\
19 \\
90 \\
45 \\
47,200 \\
92 \\
15,000 \\
850 \\
68 \\
20 \\
13 \\
300 \\
4,600 \\
130 \\
26 \\
160\end{array}$ & $\begin{array}{r}X \\
35 \\
39,100 \\
-3 \\
35 \\
X \\
9,800 \\
30 \\
7,000 \\
X \\
2 \\
7 \\
1 \\
20 \\
1,500 \\
20 \\
40 \\
220\end{array}$ & $\begin{array}{r}190 \\
55 \\
312,400 \\
7 \\
11 \\
30 \\
9,000 \\
10 \\
4,000 \\
1,000 \\
30 \\
9 \\
2 \\
2,000 \\
770 \\
20 \\
42 \\
20\end{array}$ & $\begin{array}{r}2,300 \\
230 \\
29,000 \\
74 \\
90 \\
250 \\
65,000 \\
115 \\
21,000 \\
6,700 \\
225 \\
80 \\
19 \\
180 \\
4,600 \\
120 \\
90 \\
150\end{array}$ \\
\hline
\end{tabular}

1 Includes samples from west of De Soto Canyon and north of lat $28^{\circ} \mathrm{N}$.

2 Mobile belt sediments are defined as 59 percent shale, 36 percent sandstone, 2 percent carbonate, and 3 percent evaporites. 
TABLE 4.-Bielement correlation coefficients based on analyses of surficial marine sediments on the northern continental shelf and slope of the Gulf of Mexico

[Coefficients $(r)$ are given in the upper right; numbers of samples $(n)$ upon which coefficients are based are given in the lower left]

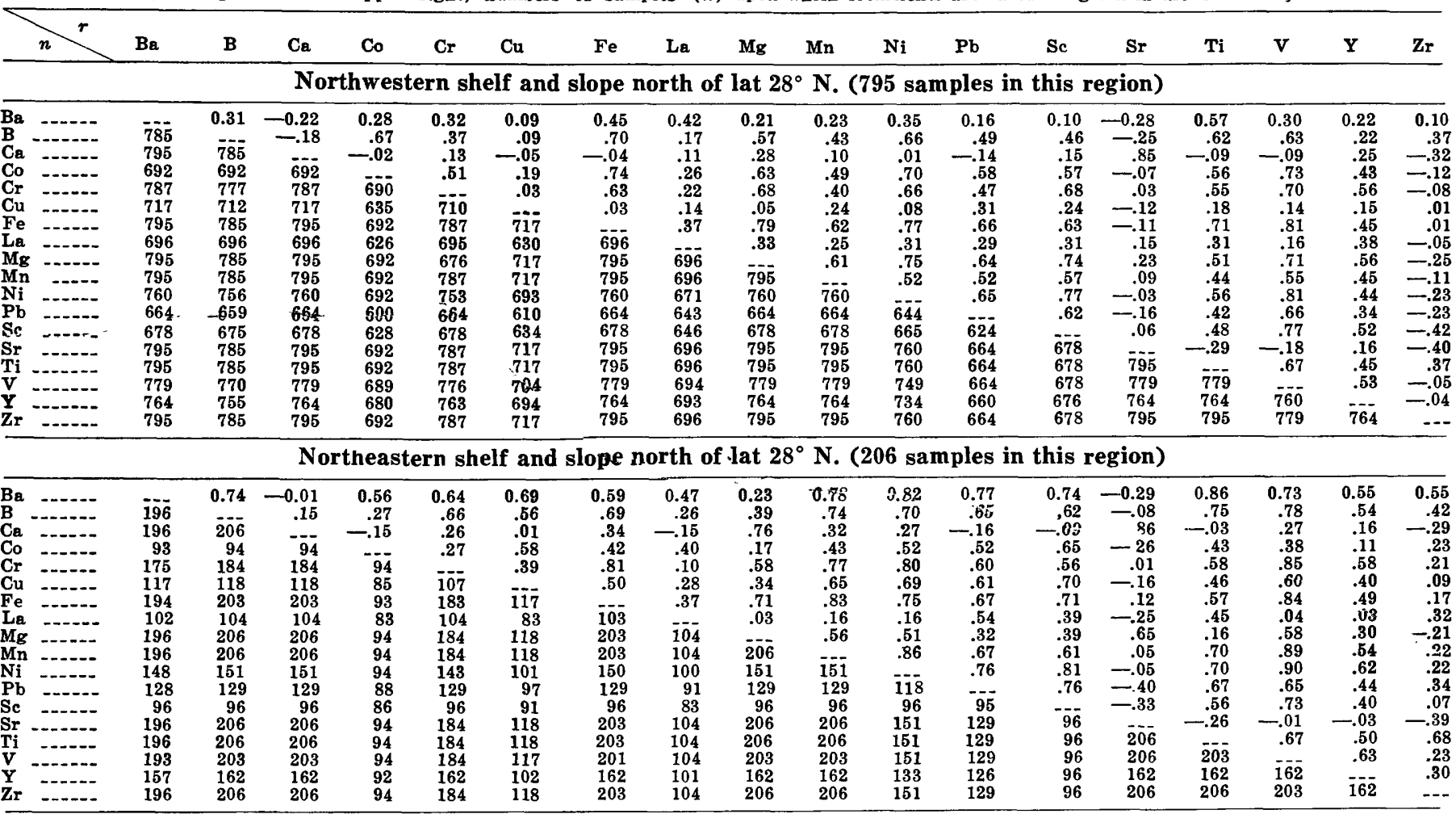

South Florida shelf and slope from lat $28^{\circ} \mathrm{N}$. to the Florida Keys (148 samples in this region)

\begin{tabular}{|c|c|c|c|c|c|c|c|c|c|c|c|c|c|c|c|c|c|c|}
\hline $\begin{array}{l}\mathrm{Ba} \\
\mathrm{B}\end{array}$ & $\begin{array}{l}-6 \overline{6} \\
67 \\
31 \\
67 \\
40 \\
67 \\
12 \\
67 \\
67 \\
60 \\
32 \\
18 \\
67 \\
67 \\
67 \\
60 \\
67\end{array}$ & $\begin{array}{r}0.60 \\
14 \overline{6} \\
33 \\
145 \\
42 \\
138 \\
23 \\
146 \\
146 \\
83 \\
41 \\
20 \\
146 \\
142 \\
136 \\
79 \\
146\end{array}$ & $\begin{array}{r}-0.61 \\
-.55 \\
-34 \\
147 \\
42 \\
139 \\
23 \\
148 \\
148 \\
84 \\
41 \\
20 \\
148 \\
144 \\
138 \\
80 \\
148\end{array}$ & $\begin{array}{r}0.69 \\
.74 \\
-.72 \\
-74 \\
34 \\
28 \\
34 \\
12 \\
34 \\
34 \\
34 \\
26 \\
18 \\
34 \\
34 \\
34 \\
34 \\
34\end{array}$ & $\begin{array}{r}0.62 \\
.48 \\
-.43 \\
.78 \\
-72 \\
139 \\
139 \\
23 \\
147 \\
147 \\
84 \\
41 \\
20 \\
147 \\
143 \\
138 \\
80 \\
147\end{array}$ & $\begin{array}{r}0.58 \\
.38 \\
-.35 \\
.21 \\
.44 \\
--- \\
42 \\
12 \\
42 \\
42 \\
40 \\
29 \\
18 \\
42 \\
42 \\
42 \\
41 \\
42\end{array}$ & $\begin{array}{r}0.78 \\
.28 \\
-.46 \\
.71 \\
65 . \\
.49 \\
--7 \\
23 \\
139 \\
139 \\
84 \\
41 \\
20 \\
135 \\
139 \\
133 \\
80 \\
139\end{array}$ & $\begin{array}{r}0.51 \\
.15 \\
-.55 \\
-.16 \\
.50 \\
.52 \\
.75 \\
-.-5 \\
23 \\
23 \\
12 \\
12 \\
12 \\
21 \\
23 \\
23 \\
20 \\
23\end{array}$ & $\begin{array}{r}-0.28 \\
.02 \\
.22 \\
.05 \\
.02 \\
-.01 \\
-.27 \\
-.43 \\
-148 \\
84 \\
41 \\
20 \\
144 \\
148 \\
138 \\
80 \\
148\end{array}$ & $\begin{array}{r}0.73 \\
.28 \\
-.38 \\
.33 \\
.38 \\
.53 \\
.75 \\
.68 \\
-.29 \\
--\overrightarrow{84} \\
41 \\
20 \\
144 \\
148 \\
138 \\
80 \\
148\end{array}$ & $\begin{array}{r}0.78 \\
.54 \\
-.52 \\
.67 \\
.60 \\
.61 \\
.81 \\
.39 \\
-.42 \\
.83 \\
--\overline{37} \\
18 \\
84 \\
84 \\
84 \\
66 \\
84\end{array}$ & $\begin{array}{r}0.47 \\
.20 \\
-.13 \\
.05 \\
.18 \\
.67 \\
.46 \\
.38 \\
-.01 \\
.49 \\
.39 \\
-.16 \\
41 \\
41 \\
41 \\
34 \\
41\end{array}$ & $\begin{array}{r}0.82 \\
.88 \\
-.77 \\
.66 \\
.67 \\
.87 \\
.85 \\
.95 \\
.10 \\
.44 \\
.76 \\
.70 \\
-72 \\
20 \\
20 \\
20 \\
20 \\
20\end{array}$ & $\begin{array}{r}-0.67 \\
-. .22 \\
.51 \\
-.73 \\
-34 \\
-.39 \\
-.75 \\
-.74 \\
.44 \\
-.75 \\
-.79 \\
-.18 \\
-.61 \\
-17 \overline{1} \\
138 \\
80 \\
138\end{array}$ & $\begin{array}{c}0.81 \\
.64 \\
-.59 \\
.63 \\
.65 \\
.59 \\
.71 \\
.69 \\
-.18 \\
.73 \\
.79 \\
.39 \\
.89 \\
-.58 \\
-135 \\
80 \\
144\end{array}$ & $\begin{array}{r}0.68 \\
.55 \\
-.67 \\
.71 \\
.62 \\
.47 \\
.79 \\
.68 \\
-.34 \\
.73 \\
.83 \\
.22 \\
.75 \\
-.75 \\
.80 \\
-8 . \\
80 \\
138\end{array}$ & $\begin{array}{r}0.50 \\
.12 \\
-.33 \\
.37 \\
.48 \\
.17 \\
.69 \\
.49 \\
-.13 \\
.56 \\
.74 \\
.72 \\
.18 \\
-.57 \\
.54 \\
.64 \\
--.80\end{array}$ & $\begin{array}{r}0.64 \\
.56 \\
-.60 \\
.65 \\
.60 \\
.54 \\
.47 \\
.71 \\
-.19 \\
.41 \\
.44 \\
.61 \\
.22 \\
-.39 \\
.71 \\
.67 \\
.32 \\
-. .5\end{array}$ \\
\hline
\end{tabular}

based on a single sample which varies by only one class from neighboring samples may be meaningless. However, individual values that differ by more than two classes from surrounding sample points are considered to be significant.

In general, the concentrations of most elements are highest in the silty and clayey sediments on the continental slope off south Texas, on the outer shelf and slope off central Louisiana, and in the lower reaches of the De Soto Canyon. Terrigenous material is presently being deposited in these regions (Curray, 1960; Ludwick, 1964). In the sediments on the central Texas shelf southeast of Galveston, and on the south Florida shelf, the amounts of trace and minor elements are comparatively low.
In the relict sediments of the shelf southeast of Galveston, subaerial weathering during the Pleistocene sea-level fluctuations has depleted the supply of trace and minor elements. Those elements which occur in chemically resistant minerals, however, show a relative enrichment in these sediments. For example, Holmes (1971) demonstrated that the zirconium enrichment in the sediments of this region marks relict strandlines. The calcium, strontium, and magnesium in a few samples from this area represent relict shelly sediments. These sediments are probably lagoonal material deposited at some epoch during the Pleistocene.

On the south Florida shelf, the sediments are predominantly carbonates. These formed primarily 
from chemical species in sea water which is depleted in trace elements and reflect the chemistry of the sea water. As a result, carbonate sediments are similarly depleted in trace and minor elements with the exception of strontilim and magnesium.

Superimposed on these regional patterns are several anomalous elemental concentrations. Iron and manganese are enriched in the sediments on the upper slope south of Galveston and on the central and lower sections of the De Soto Canyon. The vertical concentration patterns of iron and manganese in cores from these areas indicate that both elements have become concentrated at the surface, possibly the result of upward migration of these elements within the sediment column (unpub. data). In the De Soto Canyon region, the surficial sediments also contain greater amounts of barium, cobalt, copper, magnesium, and nickel than the surrounding sediments. Jenne (1968) has pointed out that the chemical complexes of iron and manganese which are free to migrate also act as chemical "sinks" for other elements. This may account for the high concentration of other elements in this region.

Along the upper slope south of Louisiana, the high calcium and strontium content of the sediments reflects the presence of the carbonate banks, for example, the Flower Gardens (Parker and Curray, 1956). A similar calcium and strontium anomaly on the upper reaches of the De Soto Canyon denotes the carbonate bank present on the rim of the canyon (Ludwick and Walton, 1957).

Sediment samples taken in the vicinity of bay and river mouths often have a high concentration of trace elements. Directly seaward of Galveston Bay, barium, copper, iron, lanthanum, and lead are relatively high. South of Mobile Bay, barium, copper, iron, lead, scandium, titanium, vanadium, and yttrium are anomalously high. West of the delta of the Mississippi, barium, boron, cobalt, copper, iron, lanthanum, nickel, lead, titanium, vanadium, and yttrium are concentrated relative to the surrounding sediment. Although it is difficult to determine the origin of these trace elements, their disposition suggests that they are deposited almost immediately after entering the marine environment. To determine which elements occur naturally and which are artificially introduced by man will require a more extensive investigation into the chemical nature and the distribution of these elements in the sediments, organisms, and waters of these areas.

On the south Florida shelf, the sediments surrounding the Dry Tortugas show a high content of boron, chromium, nickel, and strontium, attributed to the biologic activity in the region. The mechan- isms resulting in these concentrations, however, must await more extensive laboratory and field analysis.

The data summarized in tables 2-4 show both differences and similarities of the regions. The geometric means (table 2) and the arithmetic means (table 3) show the general decrease in iron, lanthanum, manganese, titanium, vanadium, and zirconium from the terrigenous clastics of the northwestern shelf to the carbonates of the south Florida shelf. Boron, chromium, cobalt, copper, lead, nickel, scandium, and yttrium appeâr to be nearly equal in both the northwestern and northeastern shelf sediments. Calcium, strontium, and magnesium increase toward the more carbonate sediments of south Florida.

The average compositions for major sedimentary materials (table 3 ) have been reported by Horn and Adams (1966) and Turekian and Wedepohl (1961). As the sediments of the shelf are varied in type, regional comparison will yield little information. However, Horn and Adams (1966) modeled the chemical composition of a sedimentary class termed "mobile belt sediments." This class, modeled after the sediments in the North American Gulf of Mexico coastal plain, was defined as consisting of 59 percent shale, 36 percent sandstone, 2 percent carbonate, and 3 percent evaporites. Element-by-element comparison of the average abundances for each region with the element composition of the mobile belt sediments shows that barium, lanthanum, lead, and zirconium are significantly higher than average in the northwestern area. In the northeastern area, only lanthanum, lead, magnesium, manganese, and yttrium have an average abundance greater than the mobile belt sediments. The significance of most of these differences is not clear, but the large concentration of barium in the sediments of the northwestern Gulf may be attributed to the extensive use of barite in drilling mud for oil exploration in the Southwest during the last few decades.

Table 4 gives the calculated correlation coefficients. The purpose of this analysis is to quantify and evaluate correlations which may be intuitively apparent, as well as to focus attention on relationships that are not as clearly discernible. Although these relationships are not conclusive, they do yield evidence suggesting certain chemical and mineral relationships. For example, high correlation between iron, vanadium, nickel, chromium, lead, cobalt, manganese, and magnesium in the terrigenous clastic sediments of the northeastern and northwestern Gulf shelf suggests that these elements are associated with clay minerals. This relationship has been suggested by 
Jenne (1968) and also has been shown to exist in the sediments of the Gulf of Paria, off Venezuela, by Hirst (1962).

The semiquantitative data on the distribution of minor and trace elements in the sediments on the northern shelf of the Gulf of Mexico have estab. lished a geochemical base for further studies. As the data presented in this report were based on the analysis of the bulk sample, no new precise knowledge was obtained concerning the marine chemistry of the metals. The statistical summarization and analvses of the data also do not yield the precise information needed to understand the marine geochemical cycle of the elements. However, the data are sufficiently detailed for future planning for such studies.

\section{REFERENCES CITED}

Antoine, John, Bryant, William, and Jones, Bill, 1967, Structural features of the continental shelf, slope, and scarp, northeastern Gulf of Mexico: Am. Assoc. Petroleum Geologists Bull., v. 151, no. 2, p. 257-262.

Cohen, A. C., Jr., 1959, Simplified estimators for normal distribution when samples are singly censored or truncated: Technometrics, v. 1, no. 3, p. 217-237.

Curray, J. R., 1960, Sediments and history of Holocene transgression, continental shelf, northwest of Gulf of Mexico, in Shepard, F. P., and others, eds., Recent sediments, northwest Gulf of Mexico: Tulsa, Okla., Am. Assoc. Petroleum Geologists, p. 221-266.

Grime, D. J., and Marranzino, A. P., 1968, Direct-current arc and alternating-current spark emission spectrographic field methods for the semiquantitative analysis of geologic materials: U.S. Geol. Survey Circ. 591, 6 p.

Hirst, D. M., 1962, The geochemistry of modern sediments from the Gulf of Paria; II, The location and distribution of trace elements: Geochim. et Cosmochim. Acta, v. 26, p. 1147-1187.

Holland, W. C., compiler, 1970, Bathymetric maps, eastern continental margin, U.S.A., Sheet 3, Northern Gulf of
Mexico: Tulsa, Okla., Am. Assoc. Petroleum Geologists, scale $1: 1,000,000$.

Holmes, C. W., 1971, Zirconium on the continental shelfpossible indicator of ancient shoreline deposition, in Geological Survey research 1971: U.S. Geol. Survey Prof. Paper 750-C, p. C7-C12.

Horn, M. K., and Adams, J. A. S., 1966, Computer-derived geochemical balances and element abundances: Geochim. et Cosmochim. Acta, v. 30, p. 279-297.

Jenne, E. A., 1968, Controls on $\mathrm{Mn}, \mathrm{Fe}, \mathrm{Co}, \mathrm{Ni}, \mathrm{Cu}$, and $\mathrm{Zn}$ concentrations in soils and waters-The significant role of hydrous $\mathrm{Mn}$ and $\mathrm{Fe}$ oxides, in Trace inorganics in water-Am. Chem. Soc., 153d Ann. Mtg., Miami Beach, Fla., 1967, Div. Water, Air and Waste Chemistry Symposium: Washington, D.C., Am. Chem. Soc. (Adv. Chemistry Ser. 73), p. 337-387.

Ludwick, J. C., 1964, Sediments of northeastern Gulf of Mexico, in Miller, R. L., ed., Papers in marine geology, Shepard Commemorative Volume: New York, Macmillan Co., p. 204-238.

Ludwick, J. C., and Walton, W. R., 1957, Shelf-edge calcareous prominences in northeastern Gulf of Mexico: Am. Assoc. Petroleum Geologists Bull., v. 41, no. 9, p. 2054-2101.

Lynch, S. A., 1954, Geology of the Gulf of Mexico, in chap. 2 of Gulf of Mexico-its origin, waters, marine life: U.S. Fish and Wildlife Service Fishery Bull. 89, p. 6786.

Miesch, A. T., 1967, Methods of computation for estimating geochemical abundance: U.S. Geol. Survey Prof. Paper 574-B, $15 \mathrm{p}$.

Parker, R. H., and Curray, J. R., 1956, Fauna and bathymetry of banks on the continental shelf, northwest Gulf of Mexico: Am. Assoc. Petroleum Geologists Bull., v. 40 , no. 10 , p. $2428-2429$.

Shacklette, H. T., Hamilton, J. C., Boerngen, J. G., and Bowles, J. M., 1971, Elemental composition of surficial material in the conterminous United States: U.S. Geol. Survey Prof. Paper 574-D, 71 p.

Sichel, H. S., 1952, New methods in statistical evaluation of mine sampling data: Inst. Mining and Metallurgy Trans., v. 61 , p. 261-288.

Turekian, K. K., and Wedepohl, K. H., 1961, Distribution of the elements in some major units of the Earth's crust: Geol. Soc. America Bull., v. 72, no. 2, p. 175192. 
